LUCJAN GUCMA, ANDRZEJ BĄK

Maritime University of Szczecin, Poland

\title{
STOCHASTIC MODEL OF SHIPS TRAFFIC CAPACITY AND CONGESTION - VALIDATION BY REAL SHIPS TRAFFIC DATA ON ŚWINOUJŚCIE - SZCZECIN WATERWAY
}

\begin{abstract}
Paper presents validation of previously created stochastic ships traffic stream model by the real data of ships delays on Świnoujście - Szczecin waterway. The model is mostly based on Monte Carlo methodology. The model is microscopic which means that each ship's model is treated as separate object possessing given attributes. As the main parameter of presented validation total waiting (delay) time of ships have been applied. The time of ships delays was possessed from Szczecin VTS centre and compared with the model output.
\end{abstract}

\section{Keywords:}

ship traffic stream model, waterway capacity, ship intensity, congestion, ship intensity, ship traffic streams.

\section{INTRODUCTION}

The increase of traffic in port area demands new tools for traffic optimization assessment of different marine traffic engineering solutions and developing traffic control methods needs especially within VTS. The analytical models used for capacity estimation are based on ship domain theory are static and does not 
reflect stochastic nature of ships traffic process. To overcome this stochastic models are created [Groenveld, Hoek, 2000]. Some models of capacity take into consideration alternative passing [Bačkalić, Škiljaica, 1998]. Model for traffic optimization with use of discrete optimization for Kiel Canal have been developed and presented in [Mohring et al., 2005]. There are models used for optimization of maritime traffic that are based on Petri net approach [Kezic, 2005] or genetic algorithms [Gudelj et. al., 2012]. Several models have been developed with use queue theory [Mou et al., 2005], cellular automata [Feng, 2013] or microscopic approach. Usually domain models are applied [Zhou H. et al., 2013] where domain is defined as area where navigator intentionally keep free from the other ships. None of above Authors presented validation of created models with real data especially in scope of ships delays and queues. Recently some models of traffic stream have been created also by authors of this study. The purpose of presented model creation was to compare future design of waterway system in scope of traffic efficiency solutions [Gucma et al., 2015] and to investigate influence of ships with dangerous cargo (LPG) on other traffic performance in the Świnoujście Szczecin waterway [Gucma et al., 2016].

It should be noted that there are class of maritime risk assessment models using sometimes very comprehensive models of ships traffic as the major risk factor, for example: model used for risk assessment of ship collisions in Aegean Sea [Ventikos, Rakas, 2015], model used for collision of tankers with passengers ships probability estimation for Gulf of Finland [Goerlandt, Kujala, 2011], model of maritime risk of ships navigation along Delaware river [Altiok, 2011].

In authors opinion there are currently three models of traffic with certain degree of complexity capable to solve real traffic problems in ports that are: HarbourSim developed by R. Groenveld, Laboratory of Port Security model, and SimPlus company model. The major problem with those models is lack of detailed description of its functioning. The main goal of this paper is validation of created ship traffic simulation model with possessed real data form ships traffic centre VTS. The observation of real traffic delays have been made and compared with model results.

Usually two different criterions are applied for assessing marine traffic systems in scope of traffic streams parameters, where first was applied:

- time of ships delay and its distribution;

- mean queue of ships waiting with its distribution. 


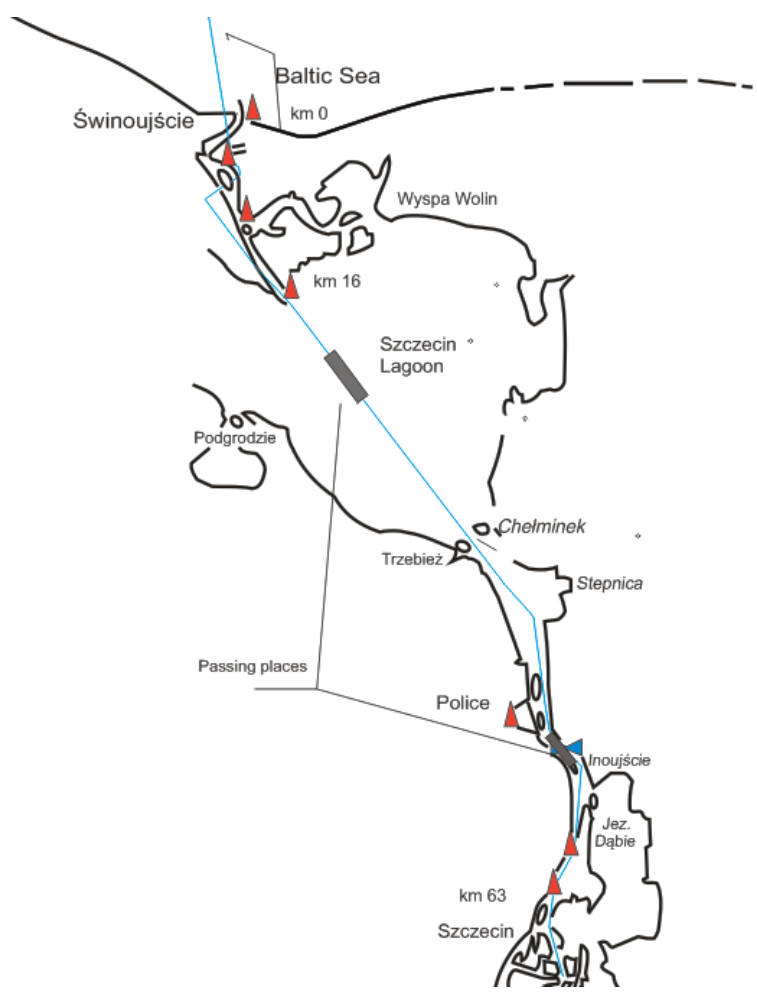

Fig. 1. Layout of Świnoujście — Szczecin waterway with passing places

\section{MICROSCOPIC STOCHASTIC MODEL OF SHIPS TRAFFIC}

The created simulation model of ships traffic on the waterway for presented study has following features:

- microscopic, that means that every ship is considered separately as an object;

- domain based (the distances of following ships are based on ships domain theory);

- stochastic, where some parameters like ships generators, ship length, draught, speed are modelled as random variables generated from its distributions mostly by Monte Carlo principle;

- one dimensional — the movement of ships is modelled in one dimension only (along the waterway); 
- kinematic — the ships are modelled as line interval (of length L) moving with uniform speed along the given section of waterway, speed changes (if any) are immediate.

The main algorithm of the model is presented in Figure 2. The model has several outputs, where the main are as follows:

- time of delay in respect to ideal situation without delays;

- queue parameters in respect to ship categories and number of ships waiting;

- passing and overtaking points with the ships categories.

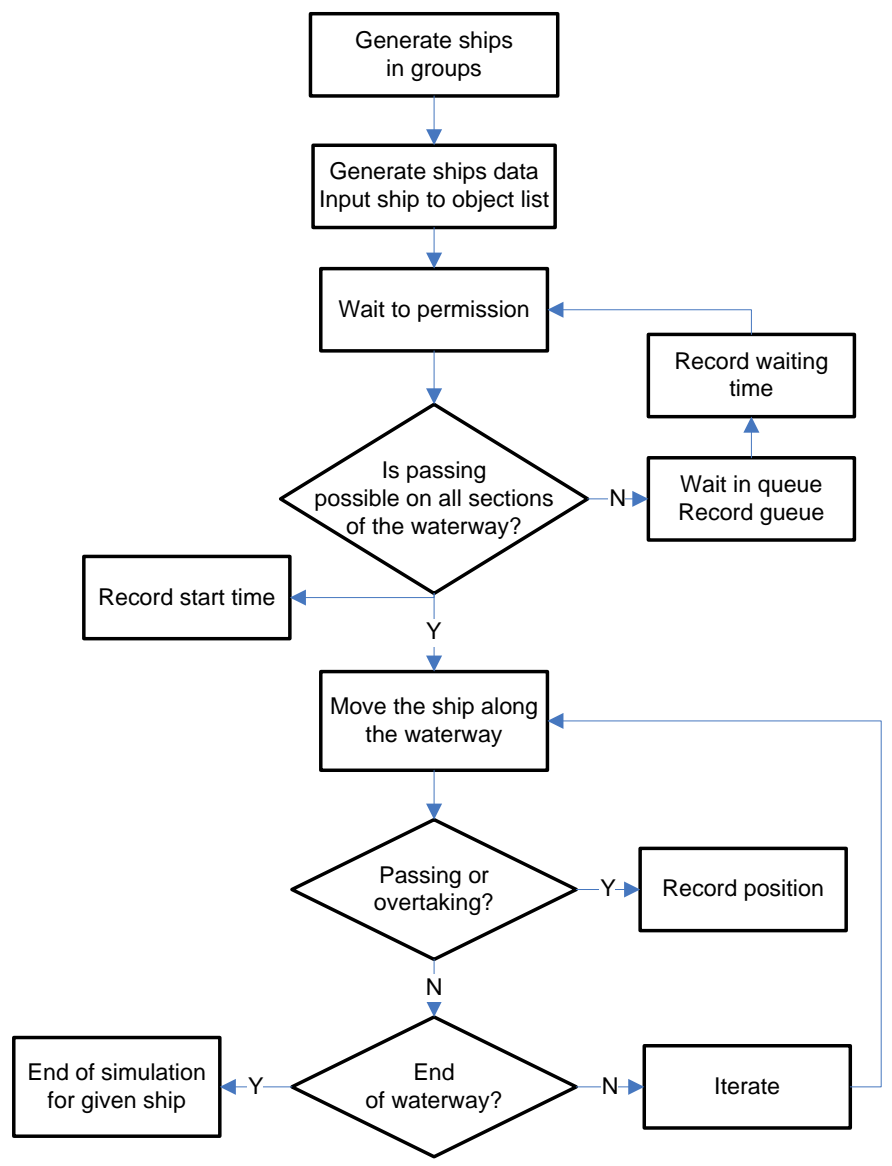

Fig. 2. Stochastic microscopic simulation model of ships traffic in Świnoujście - Szczecin waterway 
The model is written in Object Pascal language and Lazarus compiler distributed by Open GPL licence. Model has very simplify graphical interface the data are stored in text files. The verification of internal consistence and errorless of the model was done on the simplify properly chosen input data.

\section{Dynamic domain approach}

The ship domain dimensions on such very narrow waterways when the port regulation are playing major role are dependant of the section of the waterway $(x)$. The length of domain $D_{L}(x)$ could be defined as (Fig. 3):

$$
D_{L}(x)=L+D_{F}(x)+D_{A}(x)+\delta_{L},
$$

where:

$L \quad$ - ships length,

$D_{F}(x)$ - domain length forward (from zero to minimal following distance),

$D_{A}(x)$ - domain length aft (assumed as 0),

$\delta_{L} \quad$ - domain variability.

Similar formula can be used for width $D_{B}(x)$ of ships domain:

$$
D_{B}(x)=B+D_{S}(x)+D_{P}(x)+\delta_{B},
$$

where:

$B \quad$ - ships length,

$D_{s}(x)$ - domain width port,

$D_{p}(x)$ - domain width starboard,

$\delta_{B} \quad$ - domain variability.

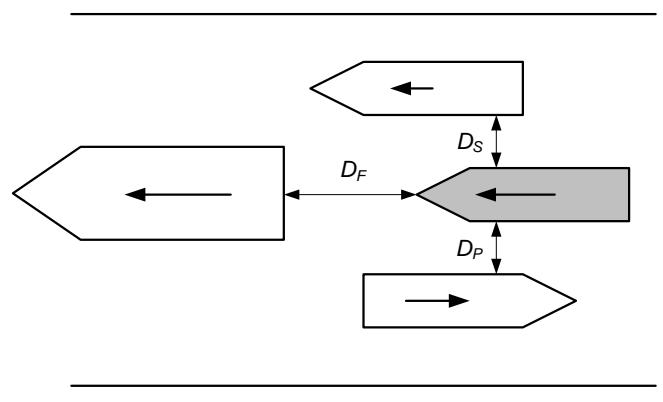

Fig. 3. Ships domain parameters in narrow waterway 
In presented study when 1-dimensional model is applied the $D_{B}(x)$ could be defined as two state variable: $D_{B}(x)=\{o(x)=(1,0) ; p(x)=(0,1)\}$ where $o(x)$ and $p(x)$ are logical variables defining if passing or overtaking of given ships is permitted on given section of waterway (0-passing/overtaking possible, 1-passing/ overtaking prohibited).

Navigator has very limited influence to adjust the length of domain on the aft $\left(D_{A}\right)$ and the following ships adjust this domain size according to ship dimensions, port regulations and intentions, so it is set to zero. The dependence of domain dimensions of $\mathrm{x}$ is the reason of variability of waterway sections and regulations inside the sections and ships speed variability in given sections. The domain variability (error) is changed according to navigators' behaviour. It is possible to model the risky, conservative behaviour or violating the regulations. This effect was neglected in this study.

The most important dimension of domain in this study is $D_{F}$. The length before the ship which navigator intend to keep free is important when one ship follows the other due to overtaking prohibition. This distance is set by regulations or by navigator itself, taking into account possibility of accidental stopping of the own ship. The accidental stopping in narrow waterway is usually made by so called step-manoeuvre which depends of ships manoeuvring characteristics. The step-manoeuvre is usually performed in steps changing set to engine in order to avoid grounding of own ship. Usually in the first phase of step-manoeuvre the 'Full Astern' is set on engine then when ship start to considerably change her course (usually to starboard) the speed telegraph is set to 'Stop' and rudder is set to 'hard to port' (or starboard depending on the ships reverse turning ability). Then the procedure is repeated. In the last step usually the anchor is dropped when it is possible. Study on step manoeuvres have been carried in [Report, 1980] for different ships size, passing the waterway with different speeds and setting on engine (Fig. 4). In presented study the dimension of domain $D_{F}$ has been set on the base of stopping distance (Fig. 3) as $D_{F}=S d(H a h, D W T)$.

Due to model level of abstraction some approximations and conditions have been applied to the model divided in three groups: ships generators, waterway characteristics, traffic control measures. 


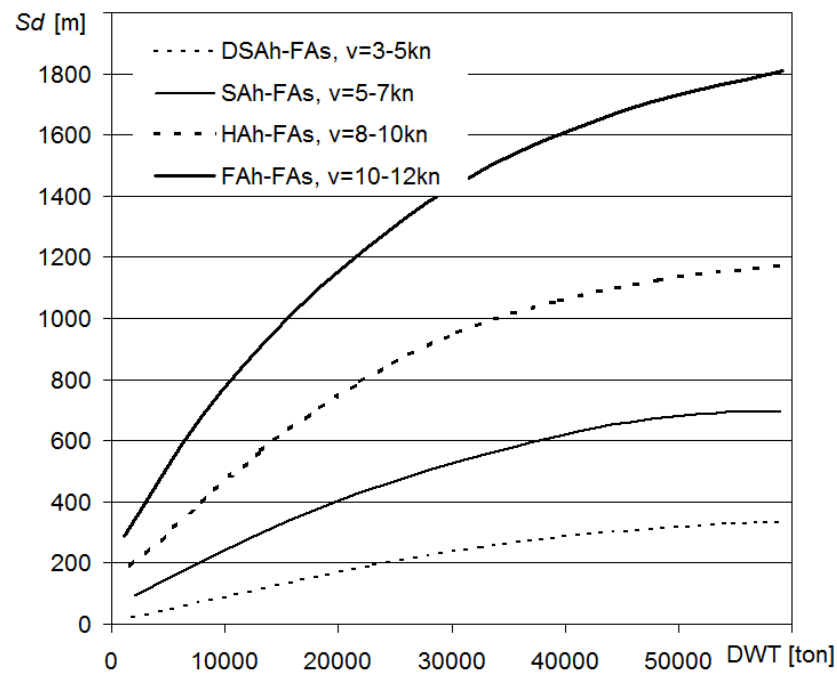

Fig. 4. Stopping distance $(S d)$ in case of accident of followed-by ship in step-manoeuvre through narrow waterway for general cargo ships [based on results of Report, 1980]

\section{Ships generators}

The model used ships generated by the Poisson distribution in groups with given intensities. The Poisson model is adequate and how good statistical consistence for under-critical intensities such as exist in analysed waterway [Kasyk, 2014; Gucma, Schefs, 2007]. Computer Poisson pseudorandom generator used in this study was created on the basis of [Zieliński, Wieczorkowski, 1997]. Length of ships in groups were generated by uniform distribution with parameters: [ $\left.L_{\max }, L_{\min }\right]$. Speed of ships was generated by normal right side cut distribution where cutting distance was set as maximum regulation speed in given section. Extended studies over the speed distribution in this area was done by author in this area [Gucma, Schefs, 2007]. The same intensities has been set to inbound and outbound ships (the choose of direction by ship was modelled by Bernoulli distribution). Main elements of the algorithm of the model are 3 loops realized by computer programme in different time intervals:

1. The loop of ships generation and the recording of their main parameters (time interval $=1 \mathrm{~h}$ ).

2. The loop of the updating of the position of ships and the record of their passage (time interval $=1 \mathrm{~min}$ ).

3. The decision loop of the check of the possibility of letting in ships on the waterway or to the queue (time interval $=10 \mathrm{~min}$ ). 
Waterway characteristics

Described by $n$ sections, defined by $\left(X_{i}, X_{i+1}\right)$, each contain width of waterway, admissible speed, and matrix of passing/overtaking possibility as Boolean matrix of dimension $4 \times 4$ (i.e. number of ships in classes).

Traffic control measures

Traffic control is mostly neglected in this study except keeping the ships in queue in case the waterway is busy. In practical situation sometimes the speed reduction is applied as traffic control measure by VTS operators.

\section{PRACTICAL APPLICATION OF CREATED TRAFFIC MODEL FOR ASSESSING DELAYS OF SHIPS AN MODEL PERFORMANCE}

In this part the case study the model is validated on real data so it should to be adjusted to real conditions on Świnoujście - Szczecin waterway. This $67 \mathrm{~km}$ length waterway is created serve Szczecin port for ships of maximal draught of $9.15 \mathrm{~m}$. For the traffic modelling purpose and due to port regulation the ships was divided on 4 classes related with ships draught ( $T$ ) [Port Regulations, 2013]:

- all ships of draught $T<6.1 \mathrm{~m}$;

- all ships of draught between $6.1 \mathrm{~m}<T<7.4 \mathrm{~m}$;

- all ships of draught between $7.4 \mathrm{~m}<T<9.1 \mathrm{~m}$;

- dangerous cargo ships (of dimensions as 1, 2 or 3 class).

The details of four ships group is presented in Table 1 . The Table 2 presents the possibilities of ships passing according to port regulation in different waterway sections.

Tab. 1. Applied division of ships on groups

\begin{tabular}{|c|c|c|c|}
\hline $\begin{array}{c}\text { Class of ship due to passing } \\
\text { possibility regulations }\end{array}$ & $\begin{array}{c}\text { Draught } \\
{[\mathrm{m}]}\end{array}$ & $\begin{array}{c}\text { Group } \\
\text { name }\end{array}$ & $\begin{array}{c}\text { Length } \\
{[\mathrm{m}]}\end{array}$ \\
\hline 1 & $T<6,1 \mathrm{~m}$ & Small & $60 \mathrm{~m}<L<100 \mathrm{~m}$ \\
\hline 2 & $6,1 \mathrm{~m}<T<7,4 \mathrm{~m}$ & Mean & $100 \mathrm{~m}<L<130 \mathrm{~m}$ \\
\hline 3 & $7,4 \mathrm{~m}<T<9,1 \mathrm{~m}$ & Large & $130 \mathrm{~m}<L<220 \mathrm{~m}$ \\
\hline
\end{tabular}


Tab. 2. Basic regulation rules according to ships passing possibilities in groups and sections of the waterway; the possibility of passing in classes

\begin{tabular}{|l|l|l|l|l|l|l|l|}
\hline \multicolumn{1}{|c|}{ From } & $\mathrm{km}$ & $\mathrm{T}$ & $\mathrm{km}$ & \multicolumn{1}{c|}{1} & \multicolumn{1}{c|}{2} & \multicolumn{1}{c|}{3} & 4 \\
\hline Glowki & 0 & Kosa & 3 & $(1,2,3) *$ & $(1,2,3) *$ & $(1,2) *$ & \\
\hline Kosa & 3 & Karsibor & 10.5 & $(1,2,3) * * *$ & $(1,2,3) * * *$ & $(1,2) * * *$ & \\
\hline Karsibor & 10.5 & $\begin{array}{l}\text { Mijanka } \\
\text { Zalew N }\end{array}$ & 15 & $(1,2,3,4) *$ & $(1,2,3,4) *$ & $(1,2,4) *$ & $(1,2,3,4) * * *$ \\
\hline $\begin{array}{l}\text { Mijanka } \\
\text { Zalew N }\end{array}$ & 15 & $\begin{array}{l}\text { Mijanka } \\
\text { Zalew S }\end{array}$ & 17 & $(1,2,3,4) *$ & $(1,2,3,4) *$ & $(1,2,4) *$ & $(1,2,3,4) * * *$ \\
\hline $\begin{array}{l}\text { Mijanka } \\
\text { Zalew S }\end{array}$ & 17 & Chełminek & 35 & $(1,2,3,4) *$ & $(1,2,3,4) *$ & $(1,2,4) *$ & $(1,2,3,4) * * *$ \\
\hline Chełminek & 35 & Mankow & 41 & $(1,2,3,4) *$ & $(1,2,4) *$ & $(1,4) *$ & $(1,2,3,4) * * *$ \\
\hline Mankow & 41 & $\begin{array}{l}\text { Mijanka } \\
\text { Police N }\end{array}$ & 50.5 & $(1,2,3,4) *$ & $(1,2,3,4) *$ & $(1,2,4) *$ & $(1,2,3,4) * * *$ \\
\hline $\begin{array}{l}\text { Mijanka } \\
\text { Police N }\end{array}$ & 50.5 & $\begin{array}{l}\text { Mijanka } \\
\text { Police S }\end{array}$ & 51.5 & $(1,2,3,4) *$ & $(1,2,3,4) *$ & $(1,2,3,4) *$ & $(1,2,3,4) * * *$ \\
\hline $\begin{array}{l}\text { Mijanka } \\
\text { Police S }\end{array}$ & 51.5 & Inski Nurt & 56 & $(1,2,3,4) *$ & $(1,2,3,4) *$ & $(1,2,4) *$ & $(1,2,3,4) * * *$ \\
\hline Inski Nurt & 56 & $\begin{array}{l}\text { Orli } \\
\text { Przesmyk }\end{array}$ & 63 & $(1,2,3) *$ & $(1,2) *$ & $(1) *$ & \\
\hline
\end{tabular}

Remarks:

* - if sum of ships lengths is less than $320 \mathrm{~m}$

** — allowed when $L$ (group 3) > $160 \mathrm{~m}$ and $L$ (group 1$)<120 \mathrm{~m}$

***_ depended of group 4 ships size

\section{Determining ships traffic parameters in Świnoujście - Szczecin waterway}

Port of Szczecin does not show significant dynamics of changes of the ships traffic, which is around 3000 and 300 ships entering per year respectively to Szczecin and to Police. The basic traffic data presented in Table 3 comes from Polish Statistical Office [GUS, 2014] covers period 2009 to 2014.

In further step three years (2013-2015) of ships traffic data from VTS Szczecin data have been analysed under consideration of ships size (length and draught). As the output of this analysis the intensities of ships in given groups are presented in Table 4. 
Tab. 3. Ship traffic in Szczecin and Police [GUS, 2014, UMS, 2015]

\begin{tabular}{|c|c|c|}
\hline Year & Szczecin & Police \\
\hline 2009 & 2775 & 173 \\
\hline 2010 & 3185 & 349 \\
\hline 2011 & 3084 & 306 \\
\hline 2012 & 2822 & 276 \\
\hline 2013 & 2872 & 220 \\
\hline 2014 & 2638 & 265 \\
\hline 2015 & 2916 & 275 \\
\hline Mean & 2899 & 266 \\
\hline Total & \multicolumn{2}{|c|}{3165} \\
\hline
\end{tabular}

Tab. 4. Yearly intensities of ships in investigated groups

\begin{tabular}{|c|c|c|c|c|}
\hline \multirow{2}{*}{ Group } & \multirow{2}{*}{$\mathrm{T}[\mathrm{m}]$} & \multicolumn{3}{|c|}{$\begin{array}{l}\text { Mean intensity in groups for Szczecin and Police } \\
\text { (mean from 2013-2015) }\end{array}$} \\
\hline & & {$[\%]$} & $\begin{array}{l}\text { [ships/year] } \\
\text { one direction }\end{array}$ & $\begin{array}{l}\text { [ships/hour] } \\
\text { two directions }\end{array}$ \\
\hline 1 small & $<6.1 \mathrm{~m}$ & $75 \%$ & 2374 & 0.542 \\
\hline 2 medium & $6.1 \mathrm{~m}$ to $7.4 \mathrm{~m}$ & $20 \%$ & 633 & 0.144 \\
\hline 3 large & $7.4 \mathrm{~m}$ to $9.1 \mathrm{~m}$ & $5 \%$ & 158 & 0.036 \\
\hline $\begin{array}{l}4 \text { dangerous } \\
\text { cargo }\end{array}$ & $\begin{array}{l}\text { variable } \\
\text { as above }\end{array}$ & & $\begin{array}{c}500 \\
\text { (included in above groups) }\end{array}$ & \\
\hline \multicolumn{2}{|c|}{ Total } & $100 \%$ & 3165 & 0.723 \\
\hline
\end{tabular}

\section{Collecting the real data of delayed ships}

The real data was collected during observations made in VTS centre located in Szczecin Harbour Office. The estimated delay times was calculated as difference between times of ship's readiness to leave the berth (in case of leaving Szczecin port) or ETA on Świnoujście breakwater (for ships calling to Szczecin a Police Port) and recorder real times. The period of data collection was from July to September 2016. The total number of observations was only 25 , but it should be noted that there is no electronic system of collecting delays, the VTS officer (co-author of this paper) made those observations during her watch. The time of single observation was 12 hours which is normal half day watch of VTS office. The total 
time of observation was therefore $12 * 25=300$ hours. In total during those observations only 17 delays were observed. The estimated parameters of traffic performance in real situation are as follows:

- Mean daily delay: $8.25 \mathrm{~h}$

- Mean yearly delay: $3012.5 \mathrm{~h}$

- Mean yearly delay: $\mathbf{1 2 5 . 5}$ days

- Number of 12 hours watch without delays: 15

The final histogram of ships observed delays, together with observations when no delay were recorded are presented in Figure 5.

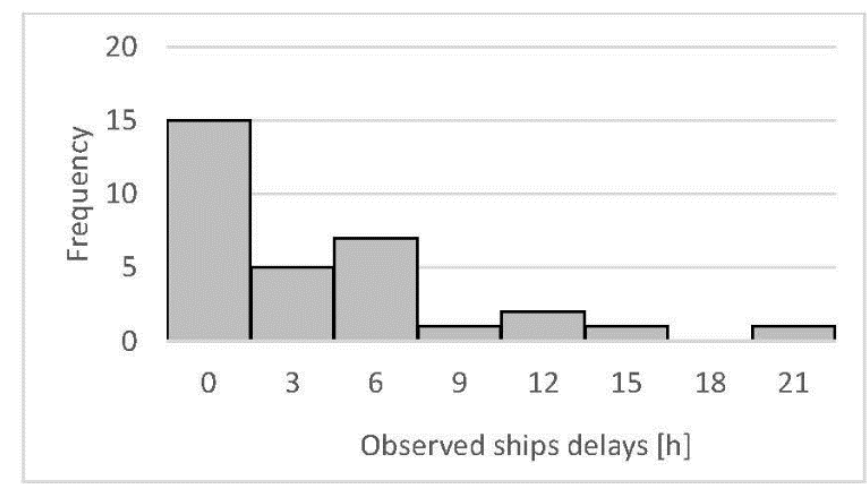

Fig. 5. Histogram of observed delays

\section{RESULTS OF SIMULATION MODEL VALIDATION BY THE REAL TRAFFIC DATA}

Time of simulation was equal 365 days (one year). Time of single simulation on average PC computer take around 1 minute. Data achieved in simulations were recorded and analysed under following parameters:

- distribution of ships queue in classes on entrance;

- distribution of ships queue in classes on departure;

- time of waterway passage without delays (ideal);

- time of waterway passage with delays in classes;

- sum of generated ships;

- mean delay per ships in classes. 
Table 5 presents result of yearly simulation for assumed traffic composition and intensity. In practical situation such delays will be reduced due to human traffic control influence.

Tab. 5. Results of one year of traffic simulations for traffic applied traffic intensity

\begin{tabular}{|l|c|c|c|c|c|}
\hline Ships class & 1 & 2 & 3 & 4 & Sum/Mean \\
\hline Class name & Small & Mean & Large & Dangerous & \\
\hline $\begin{array}{l}\text { Time of ships on the waterway } \\
\text { without delay [days] }\end{array}$ & 551 & 165 & 49 & 136 & 901 \\
\hline $\begin{array}{l}\text { Time of ships on the waterway } \\
\text { with delay [days] }\end{array}$ & 617 & 182 & 55 & 163 & 1018 \\
\hline Total ships generated (entr./dep.) & 3754 & 1121 & 333 & 927 & 6135 \\
\hline Sum of delays per year [days] & 66 & 18 & 7 & 27 & $\mathbf{1 1 7}$ \\
\hline Mean delay per 1 ship [h] & 0.16 & 0.16 & 0.17 & 0.18 & 0.17 \\
\hline
\end{tabular}

\section{CONCLUSIONS}

The created stochastic model of ship traffic flow is stable and its parameters such as queue length and number of ships are stabilising in time for different input data. The model neglects several aspects of ships traffic behaviour especially the human influence but since the relative results are used the achieved results could be representative to the class of problem solved.

In this paper the model was confronted and validated with real data obtained from 25 half day observations of real system. The delays of ships was recorded and averaged. Total delay of ships traffic in Świnoujście - Szczecin waterway is 125 ship days which is relatively large and unexpected number.

The model with input parameters as close as it was possible to which observations were made produced total delay of 117 ship days which is very close to the real observations.

The intelligent traffic control should be used for minimising delays of ships and optimize the traffic. Future passing place in Szczecin Lagoon will smoother significantly the traffic parameters. 


\section{REFERENCES}

[1] Almaz O. A., Or I., Özbaş B., Investigation of the Transit Maritime Traffic in the Strait of Istanbul Through Simulation Modeling and Scenario Analysis, 'International Journal of Simulation, Systems, Science \& Technology’, 2006, Vol. 7.

[2] Altiok T., Port Security/Safety, Risk Analysis and Modelling, 'Annals of Operations Research', 2011, Vol. 187.

[3] Bačkalić T., Škiljaica V., Modelling of Vessel Traffic Process in One-Way Straits at Alternating Passing, Proceedings of the 'MARIND '98', Bulgaria, 1988.

[4] Feng H., Cellular Automata Ship Traffic Flow Model Considering Integrated Bridge System, International Journal of Service, 'Science and Technology', 2013, Vol. 6.

[5] Goerlant F., Kujala P., Traffic simulation based ship collision probability modeling, 'Reliability Engineering and System Safety', 2011, Vol. 96.

[6] Groenveld R., Hoek C. V. A., A simulation tool to assess nautical safety in port approaches, Seminar of the Permanent Commission for Development and Cooperation of PIANC, Argentina, 2000.

[7] Gucma L., Bąk A., Gucma M., Stochastic model of ships traffic congestion in waterways for two different traffic solutions based on Świnoujście - Szczecin case study, International Workshop on Nautical Traffic Models, Espoo, Finland, 2015.

[8] Gucma L., Schefs S., Ships speed study on Świnoujście - Szczecin waterway [in Polish], Maritime University of Szczecin, 2007.

[9] Gucma L., Sokołowska S., The ships entering to Szczecin port dimensions analysis with over-normative vessels consideration, EXPLO-SHIP 2012.

[10] Gucma L., Bąk A., Sokołowska S., Hajduk J., Stochastic model of ships traffic congestion in waterways applied to determine the influence of LPG tankers introduction on ships traffic on Świnoujście - Szczecin waterway, 'Scientific Journal of Maritime University of Szczecin', 2016, No. 45 (117).

[11] Gudelj A., Kezić D., Vidačić S., Marine Traffic Optimization Using Petri Net and Genetic Algorithm, 'Traffic \& Transportation', 2012, Vol. 24.

[12] GUS Statistic Yearbook of Maritime Economy [in Polish], GUS, Warszawa Szczecin 2014.

[13] Huang S. Y., Hsu W. J., He Y., Song T., Charles D. S., Ye R., Anchorage capacity analysis using simulation, The International Conference on Harbor, Maritime \& Multimodal Logistics Modelling and Simulation HMS, 2009.

[14] Kasyk L., Probabilistic methods of ships traffic parameters modelling on restricted waters, Maritime University of Szczecin, 2014.

[15] Kezić D., Perić N., Petrović I., Petri A., Net Approach of Deadlock Prevention in Marine Traffic System, In Proceeding of the IEEE International Symposium on Industrial Electronics, Croatia, Vol. 1, 2005.

[16] Mohring R., Conflict-free real-time AGV routing, 'Operations Research Proceedings', Springer-Verlag, Berlin 2004. 
[17] Mou J. M., Tak C., Lighteringen H., Study on Collision Avoidance in Busy Waterways by Using AIS Data, 'Ocean Engineering', 2010, Vol. 37.

[18] Mou J. M., Qi C. X., Zou Z. J., Research on application of queuing theory in communication engineerin, 'Journal of Wuhan Institute of Shipbuilding Technology', 2005, No. 33.

[19] Port Regulations [in Polish], Instruction No. 3 of the Chief of Maritime Office in Szczecin, 26 July 2013.

[20] Report: The use of scientific methods of qualifying of the capacity of seaports for prognostic aims, conceptional and investment preparation [in Polish], Maritime University of Szczecin, 1980.

[21] Report: Determination of safety parmeters of Świnoujście-Szczecin waterway [unpublished report, in Polish], Maritime University of Szczecin, 2015.

[22] Ventikos N., Rakas D., Avoiding collisions, enhancing marine safety — a simplified model for the Aegean Sea, 'Scientific Journal of the Maritime University of Szczecin', 2015, Vol. 42.

[23] Zhou H., Guo G., Wu B., Nanjing Yangtze River Bridge Transit Capacity Based on Queuing Theory, 13th COTA International Conference of Transportation Professionals, 2013.

[24] Zieliński R., Wieczorkowski R., Computer generators of random numbers [in Polish], WNT, Warszawa 1997.

Received October 2016

Reviewed October 2017

Published 19.11.2017

\section{LUCJAN GUCMA}

Maritime University of Szczecin

Wały Chrobrego 1-2 Str., 70-500 Szczecin, Poland

e-mail: 1.gucma @am.szczecin.pl

\section{ANDRZEJ BĄK}

Maritime University of Szczecin

Wały Chrobrego 1-2 Str., 70-500 Szczecin, Poland

e-mail: a.bak@am.szczecin.pl

\section{SYLWIA SOKOLOWSKA}

Maritime Office in Szczecin

Stefana Batorego 4 Str., 70-207 Szczecin, Poland

e-mail: sylwia.sokolowska@gmail.com 


\section{STRESZCZENIE}

W artykule przedstawiono wyniki walidacji wcześniej stworzonego stochastycznego modelu strumienia ruchu statków przez porównanie z rzeczywistymi danymi o opóźnieniu statków na drodze wodnej Świnoujście - Szczecin. Model został zbudowany w oparciu o metodologię Monte Carlo. Jest to model z kategorii „mikroskopowych”, co oznacza, że każdy statek jest traktowany jako odrębny obiekt, cechujący się indywidualnymi atrybutami. Jako główny parametr walidacji przyjęto całkowity czas oczekiwania (opóźnienia) statków. Czas definiujący opóźnienie statków został pozyskany z centrum VTS Szczecin i porównany z wynikami modelowymi. 